Jurnal Pengabdian kepada Masyarakat

\title{
Penerapan Teknologi Mesin AC Mobil Bagi Siswa Jurusan Teknik Otomotif Di SMK Negeri 1 Losarang
}

\author{
Wardika $^{1}$, Sunanto ${ }^{2 *}$, Dedi Suwandi ${ }^{3}$, Munengsih Sari Bunga ${ }^{4}$ \\ 1,2,3,4 Politeknik Negeri Indramayu, Jl. Raya Lohbener Lama No.8 Indramayu \\ *wardika@polindra.ac.id
}

\begin{abstract}
Kata Kunci:
AC Mobil,

Kompetensi,

Alat

Praktikum.

Abstrak Kelengkapan sarana belajar praktikun dalam mencapai kompetensi bidang otomotif tentunya menjadi keharusan yang wajib terpenuhi. Melihat jumlah siswa yang ada di SMKN 1 Losarang jurusan teknik Otomotif yang begitu besar memiliki sarana praktikum yang masih terbilang sangat minim maka dengan keterbatasan sarana praktikum tersebut diperlukan adanya tambahan sarana praktikum berupa trainer mesin AC mobil untuk meningkatkan kompetensi siswa di SMK N 1 Losarang. Peningkatan kompetensi dengan memberikan trainer AC Mobil dan dilakukan pelatihan dan workshop serta memberikan free test dan post test yang diadakan sebelum dan sesudah pelatihan. Dengan adanya penerapan teknologi mesin AC mobil kompetensi siswa jurusan Otomotif mengalami peningkatan sebesar 20,5\%. Hal ini berdasarkan perbandingan nilai free test terhadap nilai post test yang telah dilakukan. Kegiatan PkM yang dilaksanakan telah memberikan dampak cukup baik bagi siswa maupun sekolah jurusan itu sendiri.
\end{abstract}

Keywords:

Car $A C$;

Competence;

Practicum

Tools.

\begin{abstract}
Completeness praktikun learning tool in achieving competence automotive field would be a necessity that must be met. Seeing the large number of students at SMKN 1 Losarang, majoring in Automotive engineering, having practicum facilities that are still relatively minimal, with the limited practical facilities, additional practical facilities are needed in the form of car AC machine trainers to improve student competence at SMKN 1 Losarang. Increased competence by providing trainer $A C$ Drives and conducted training and workshops and provide free test and post-test were conducted before and after the training. With the application of AC engine technology competence of students majoring in Automotive cars increased by $20.5 \%$. This is based on comparison of the value of the free test to post-test value that has been done. PKM activity carried out has an impact enough for both students and the school's own department.
\end{abstract}

\section{PENDAHULUAN}

SMK Negeri 1 Losarang merupakan sekolah kejuruan yang didirikan pada tahun 1999 dengan membuka 3 (tiga) jurusan yaitu Jurusan Teknik Permesinan (TM), Teknik Elektro (TE) dan Teknik Pertanian (TP). Sejak tahun 2000 perkembangan sekolah ini mengalami peningkatan yang sangat signifikan jumlah pendaftar terus tambah dari tahun ke tahun. Sehingga pada tahun 2006 sekolah ini membuka jurusan baru yaitu jurusan Otomotif dan Jurusan Komputer dan Jaringan.

Walaupun terbilang baru saat itu jurusan teknik Otomotif sangat diminati oleh calon peserta didik sehingga jurusan ini membuka 3 rombel/kelas tiap tahunnya, namun seiring peningkatan jumlah peserta di jurusan tersebut tidak diiringi peningkatan alat praktikum untuk siswa melakukan praktek. Hingga saat sekarang ini rasio jumlah alat praktikum masih terbilang sangat tinggi 1:36 dimana 1 (satu) mesin untuk 36 siswa. Hal inilah yang menjadi miris melihat sekolah dengan jumlah peminat peserta didik yang tinggi tidak memiliki perlengkapan praktikum. 
Berdasarkan analisis situasi tersebut dan selaras dengan penelitian Wardika., dkk tahun 2018 mengenai prototype mesin AC mobil yang telah dipublikasikan pada Seminar Nasional Sentrinov 2018. Hasil yang diperoleh pada penelitian sebelumnya menunjukan secara umum mesin prototype AC mobil, Temperatur rata-rata kabin pada saat RPM 1450 lebih rendah dari temperatur rata-rata kabin pada saat RPM 1000 yaitu sebesar: $4,37^{\circ} \mathrm{C}$ Kinerja nilai COP carnot pada RPM 1000 lebih besar dari nilai COP carnot pada RPM 1450 yaitu: 5,75 untuk RPM 1000 dan 5,25 untuk RPM 1450. Tujuan PkM berdasarkan hasil tersebut prototype mesin AC dapat dijadikan sebagai model/perangkat pembelajaran praktikum di jurusan Teknik Otomotif SMK Negeri 1 Losarang sehingga mampu meningkatkan kompetensi peserta didik pada jurusan tersebut. (Marwan Effendy, 2005)

\section{METODOLOGI}

Dalam melaksanakan program pengabdian kepada masyarakat penulis melakukan beberapa tahapan sebagai berikut:

$\checkmark$ Tahap pertama pengusul melakukan observasi kelokasi mitra.

$\checkmark$ Tahap kedua menganalisa permasalahan/isu yang dihadapi mitra

$\checkmark$ Tahap ketiga memberikan teknologi trainer AC mobil kepada mitra

$\checkmark \quad$ Tahap empat memberikan pelatihan dan workshop terhadap teknologi yang diberikan kepada mitra (peserta didik)

$\checkmark$ Tahap kelima melakulan evaluasi untuk mengetahui sejauh mana peningkatan kompetensi yang dimiliki siswa.

Alur pelaksanaan program pengabdian kepada masyarakat sebagai berikut:

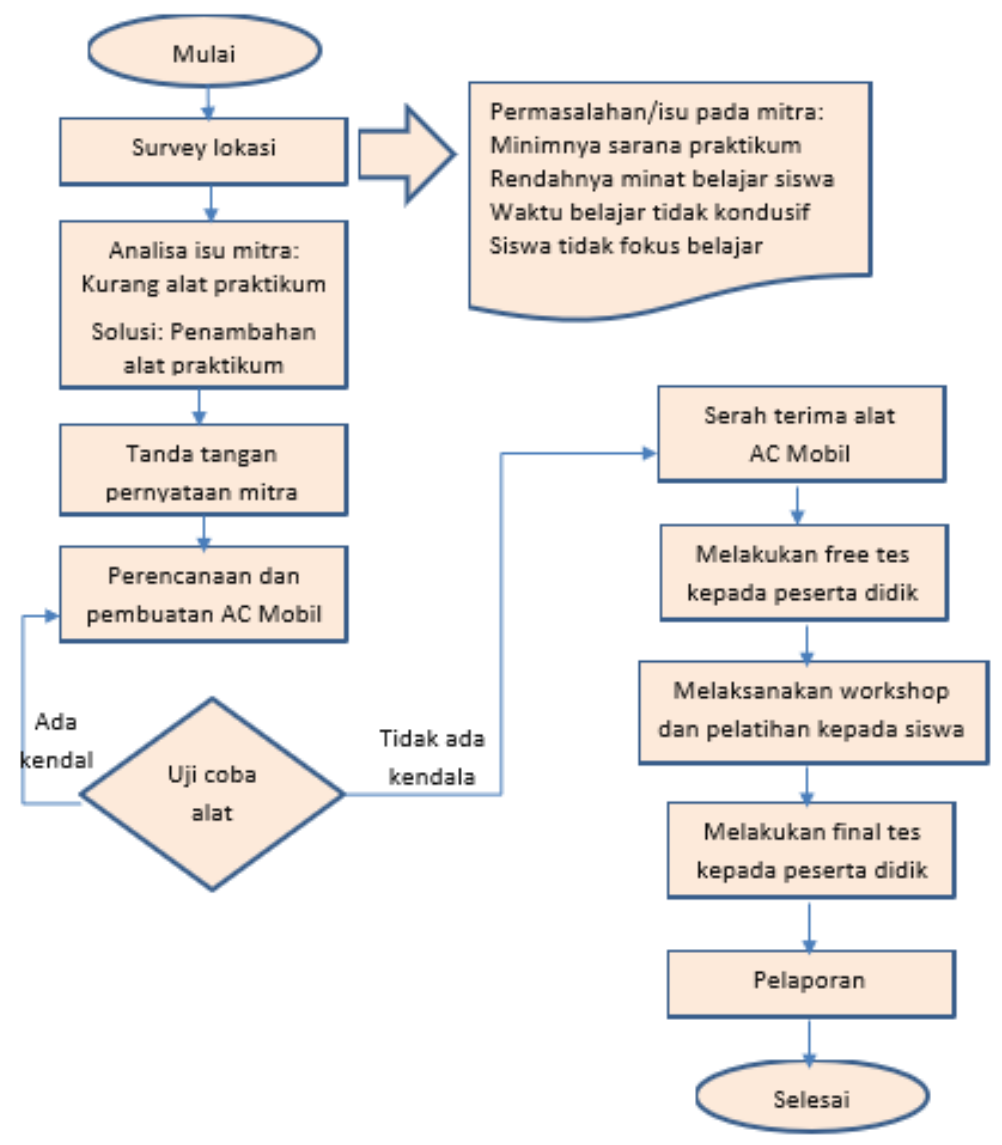

Gambar 1. Alur pelaksanaan PkM di SMK Negeri 1 Losarang 
Beberapa dokumentasi pada saat survey ke lokasi Mitra di SMK Negeri 1 Losarang tersaji dalam Gambar 2 berikut.
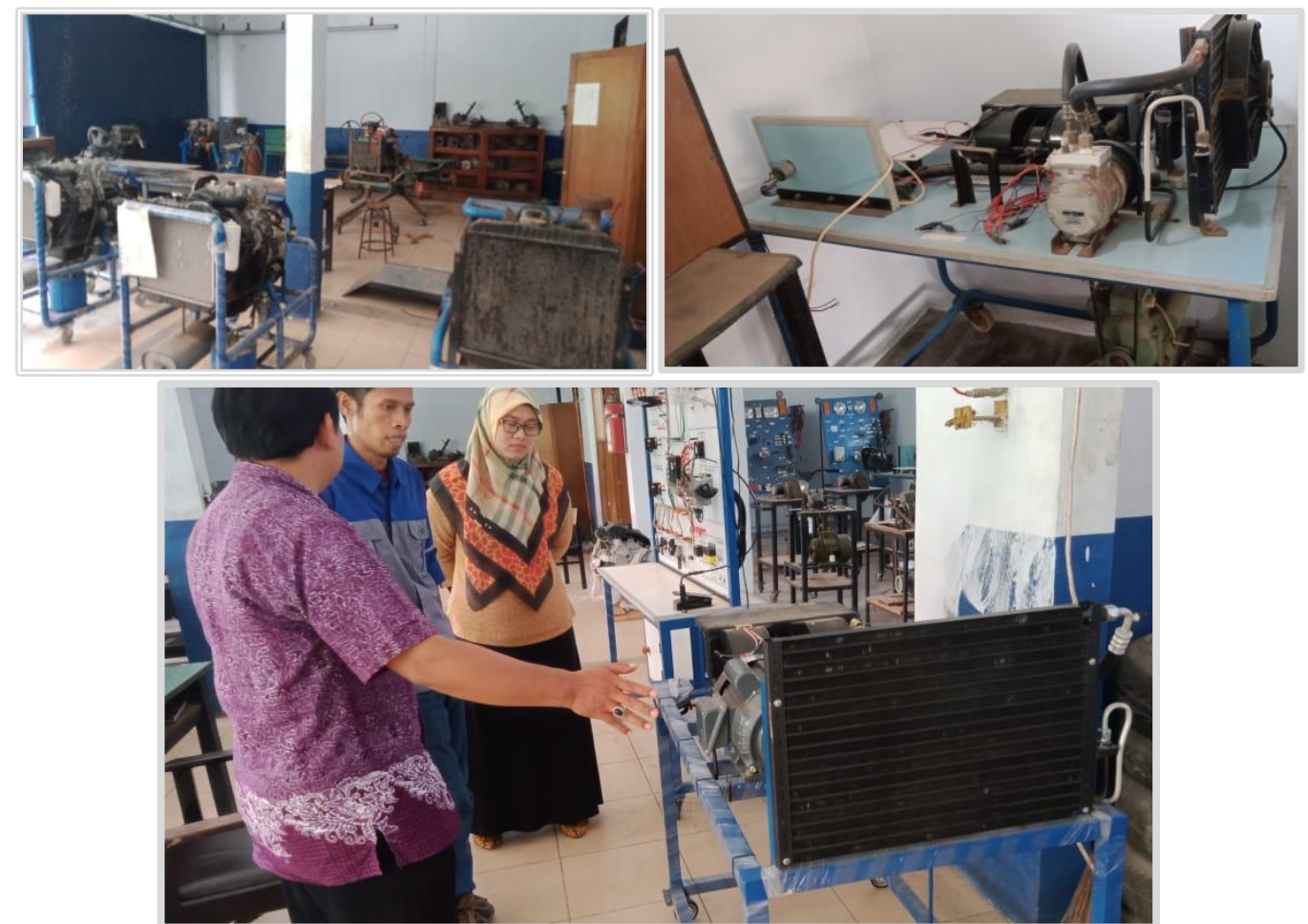

Gambar 2. Suasana bengkel dan sarana praktikum AC Mobil saat survey mitra

\section{HASIL DAN PEMBAHASAN}

Pada pelaksanaan program PkM di SMK Negeri 1 Losarang, Tim melakukan perancangan trainer AC Mobil yang akan di berikan kepada mitra, hasil perancangan dapat dilihat pada Gambar 3 berikut:
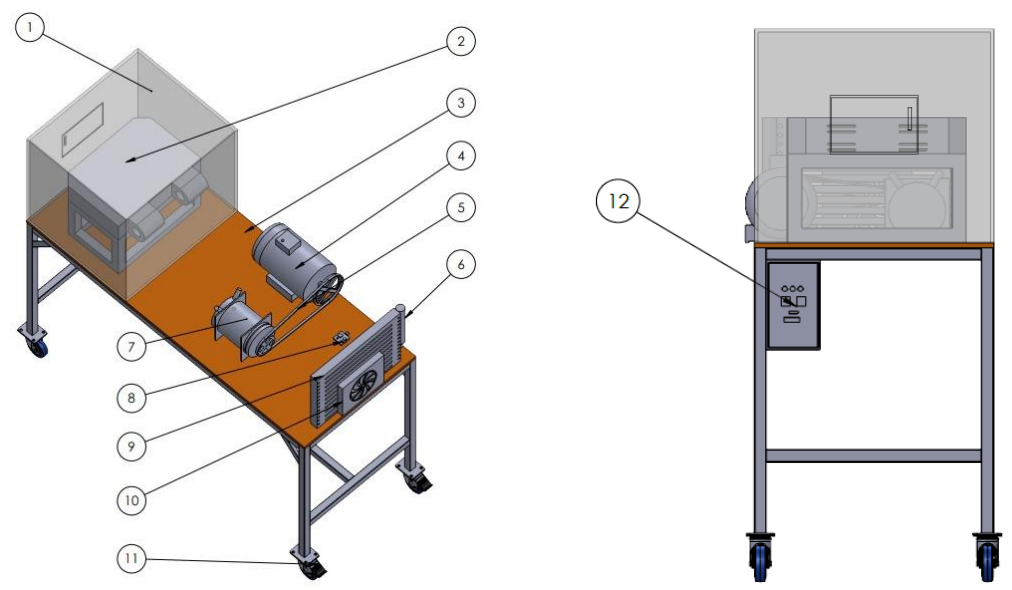

Gambar 3. Desain Rancangan I rainer AC IMobıı

Keretangan Gambar:
1. Kabin
5. V Belt
9. Kondensor
2. Evaporator
6. Filter Dryer
10. Fan Kondensor
3. Meja Trainer
7. Kompresor
11. Roda
4. Motor
8. Dimmer $12 \mathrm{~V}$
12. Panel kelistrikan 
Spesifikasi perancangan AC Mobil yang digunakan, yaitu :

a. Menggunakan kompresor Swash Plate dan refrigerant R134a.

b. Kabin untuk ruang sistem menggunakan bahan akrilik dengan tebal $5 \mathrm{~mm}$ dan berdimensi panjang $60 \mathrm{~cm}$, lebar $60 \mathrm{~cm}$ dan tinggi $50 \mathrm{~cm}$.

c. Dimensi meja trainer panjang $120 \mathrm{~cm}$, lebar $60 \mathrm{~cm}$ dan tinggi $80 \mathrm{~cm}$.

Proses pembuatan alat dapat dilihat pada Gambar 4 berikut ini:
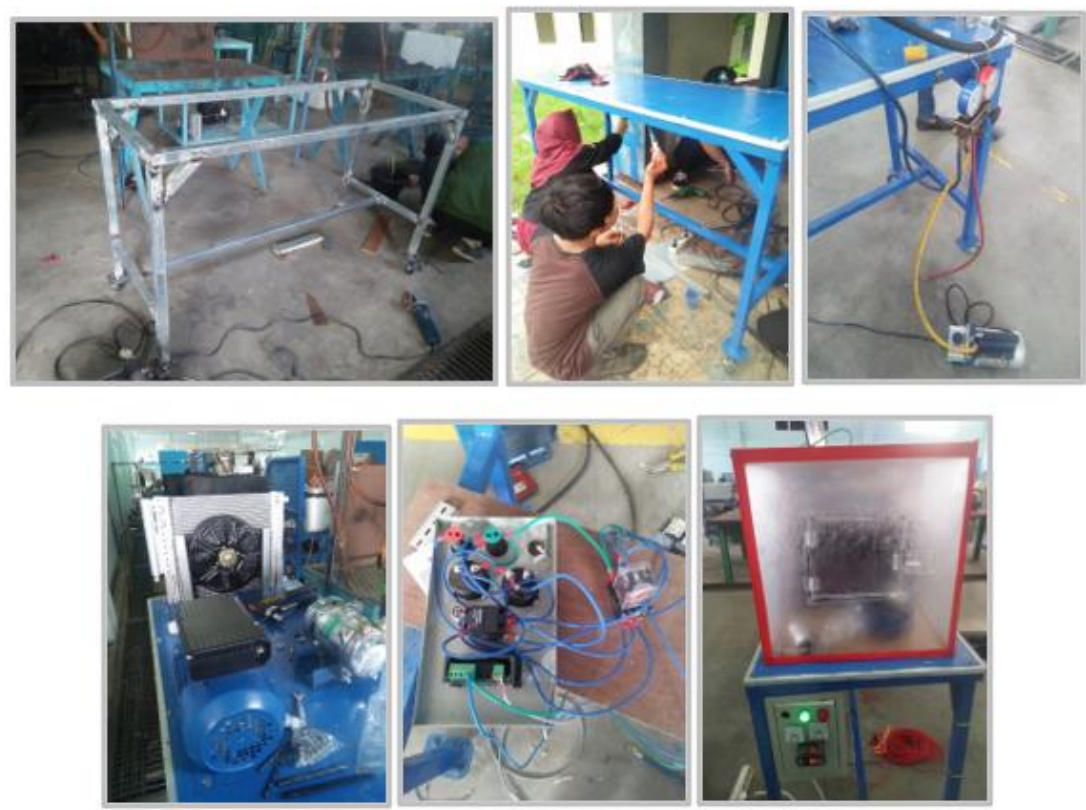

Gambar 4. Proses pembuatan alat AC mobil

Pada Gambar 4 menunjukan proses pembuatan alat AC mobil dimana pertama pembuatan kerangka meja dari bahan hollow ukuran 4 setelah itu dilakukan pengecatan meja hingga sampai penempatan komponen serta perakitan kelistrikan pada box panel. Kemudian dilakukan uji coba sistem untuk memastikan sistem bekerja dengan baik dan layak untuk di serah terimahkan. (wardika,2018)

\section{Pelaksanaan Serah terima dan workshop serta pelatihan}

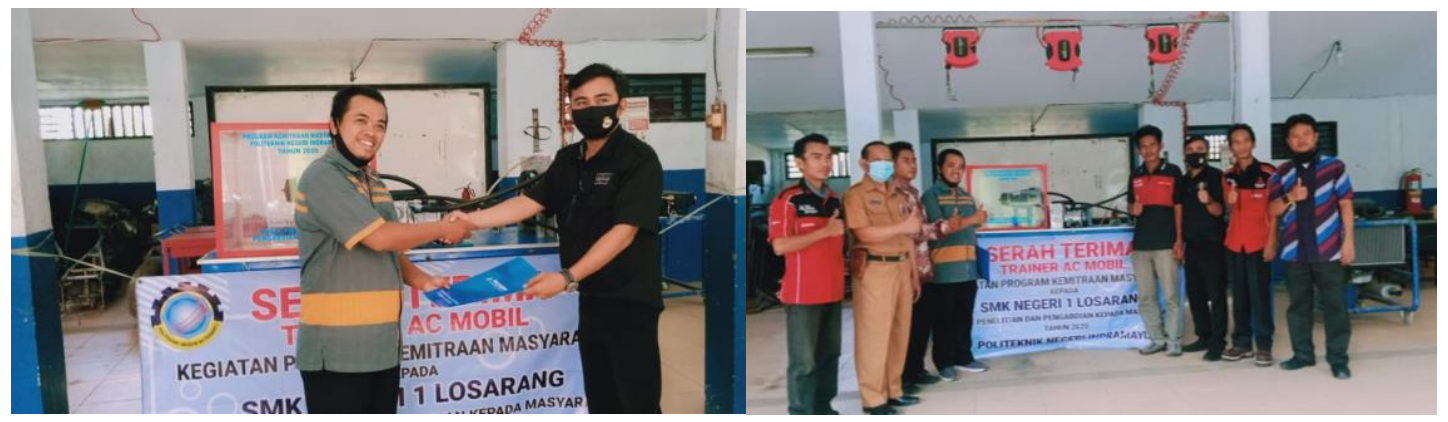

Gambar 5. Serah terima Alat Trainer AC Mobil kepada mitra

Gambar 5 memperlihatkan serah terima dilakukan oleh ketua Tim PkM kepada mitra yang diwakili oleh Wakil Kepala sekolah bidang kurikulum dan didampingi oleh ketua jurusan Otomotif beserta dengan para guru dan teknisi. 

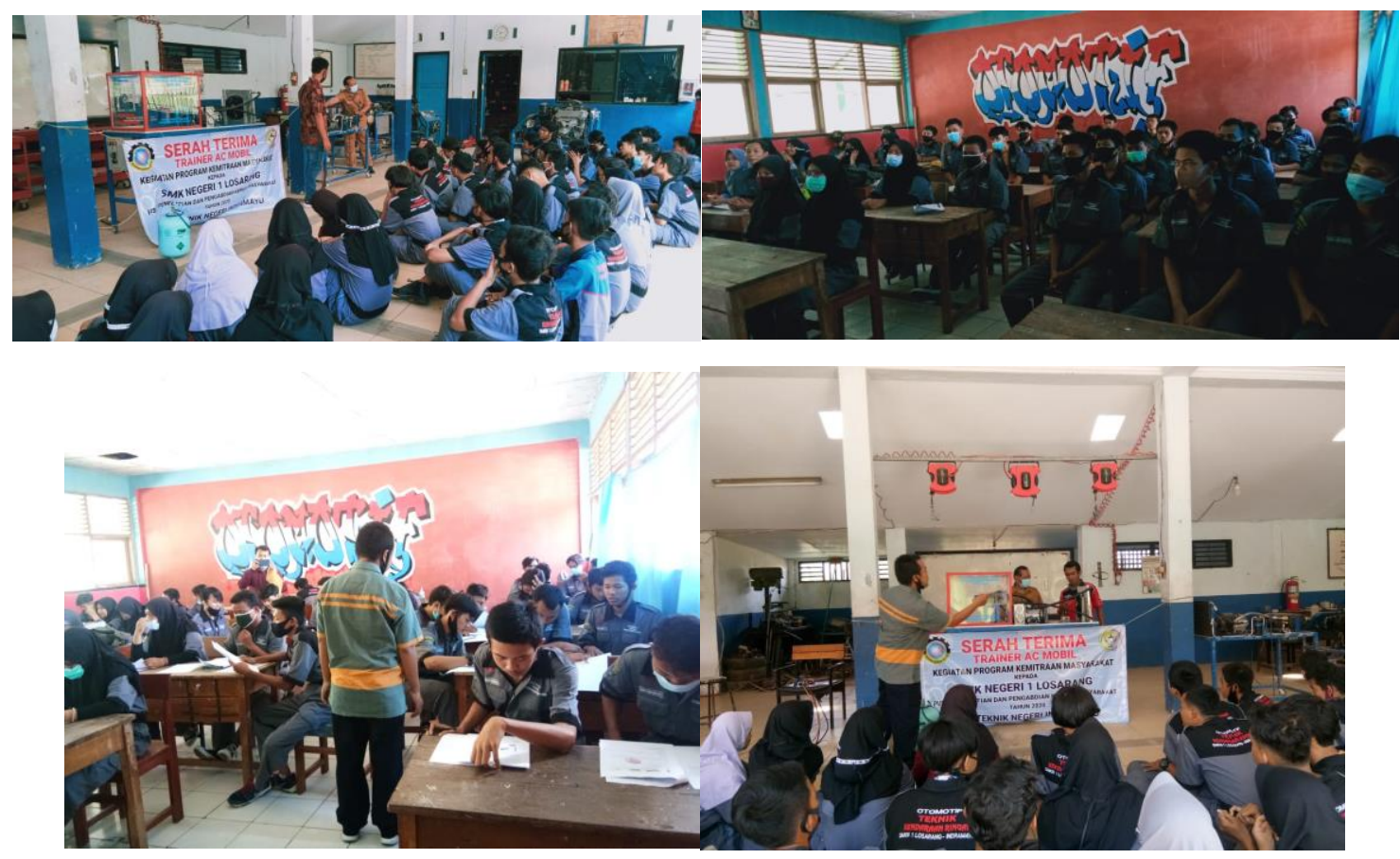

Gambar 6. Pelaksanaan Workshop dan Pelatihan kepada peserta didik

Pada Gambar 6 saat itu dilakukan free test untuk mengetahui kemampuan awal sebelum dilakukan workshop dan pelatihan. Kemudian setelah itu dilaksanaan pelatihan dan workshop untuk membekali peserta didik pada kompetensi AC Mobil. Serta ditutup dengan pelaksanaan post test. Soal yang diberikan pada saat itu adalah 30 soal pilihan ganda yang memuat seputar AC Mobil.

\section{Peningkatan Kompetensi Siswa Jurusan Otomotif}

Berdasarkan Gambar 7 menunjukan kemampuan siswa jurusan otomotif dalam menjawab soal pilihan ganda dengan jumlah soal sebanyak 30 butir sebelum pelaksanaan pelatihan dengan trainer AC Mobil, nilai yang dianggap lulus jika siswa dapat menjawab 18 butir dengan benar atau setara dangan nilai 60 sehingga terdapat $32 \%$ siswa yang dinyatakan lulus atau hanya sekitar 13 orang siswa saja dan $60 \%$ dinyatakan remedial atau sekitar 24 orang siswa serta terdapat 3 siswa yang tidak hadir. Dengan melihat data tersebut kempuan siswa yang dapat berkompetisi sementara hanya sekitar 13 peserta saja.

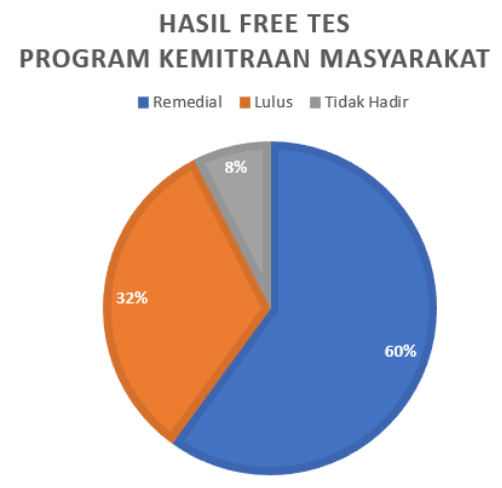

Gambar 7. Hasil Free Tes 
Selanjutnya hasil evaluasi setelah dilakukan proses penyerahan trainer serta dilakukan pelatihan dan workshop kemampuan siswa jurusan Teknik Otomotif mengalami peningkatan kompetensi yaitu ditandai dengan peningkatan kemampuan dalam menjawab soal yang sama sewaktu free tes. Hasil evaluasi menunjukan terdapat 21 orang siswa $(52 \%)$ telah dinyatakan lulus dan 18 orang siswa (45\%) masih dibawah nilai 60 atau masih remedial. Walaupun masih banyak jumlah siswa yang belum lulus namun perbandingan hasil free tes dan post tes terdapat peningkatan yang cukup baik yaitu sekitar $20,5 \%$ peningkatan yang terjadi.

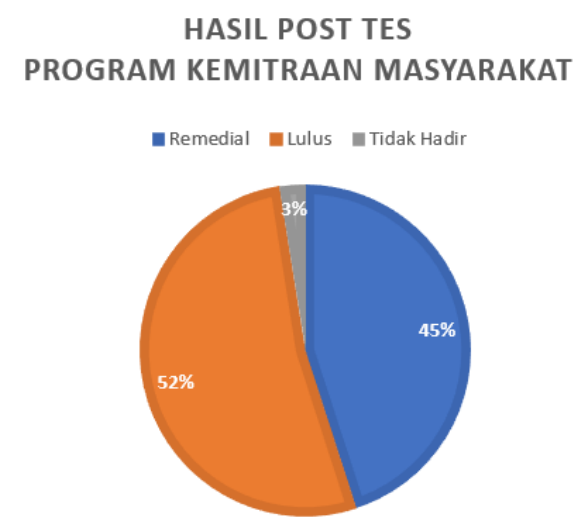

Gambar 4.11 Hasil Post Tes

Berdasarkan hasil evaluasi yang telah dilakukan selama kegiatan PkM kebutuhan trainer AC mobil memang sangat dibutuhkan dijurusan tersebut, melihat antusias dan peningkatan kompetensi yang cukup baik.

\section{KESIMPULAN}

Pelaksanaan program PkM telah selesai dengan baik dan lancar, dimana tim PkM membuat mesin AC Mobil untuk meningkatkan kompetensi dan minat belajar peserta didik di jurusan Teknik otomotif SMK Negeri 1 Losarang. Kompetensi berdasarkan hasil evaluasi post tes menunjukan peningkatan yang cukup baik yaitu sekitar 20,5\%. Setelah pelaksanaan PkM dilaksanakan sebagai tindak lanjut yang dapat dilakukan adalah dengan membuat duplkat trainer AC Mobil yang serupa sehingga rasio trainer dengan siswa menjadi 1:4 saja.

\section{Ucapan Terima kasih}

Tim Pelaksana program PkM mengucapkan terimakasih yang sebesar-besarnya kepada Politeknik Negeri Indramayu melalui Pusat Penelitian dan Pengabdian kepada Masyarakat telah memberikan pendanaan Internal tahun 2020 untuk pelaksanaan PkM sehingga berjalan dengan semestinya. Serta tidak lupa tim mengucapkan kepada mitra SMK Negeri 1 Losarang atas kerjasama yang baik sehingga pelaksanaan PkM dapat diselesaikan tepat waktu. 


\section{Daftar Pustaka}

ASHRAE Refrigeration Hand Book 2006. American Society of Heating, Refrigerating and air-conditioning Engineers, inc. Atlanta, 2006.

Wardika. Sunanto. F. Sugara and Y. T. Mulya, "Pengaruh Kecepatan Putaran Blower Evaporator Terhadap," vol. 4, no. September, 2018.

Marwan Effendy, 2005. "Pengaruh Kecepatan Putar Poros Kompresor Terhadap Prestasi Kerja Mesin Pendingin AC”. ISSN 1411-4348, Jurnal Media Mesin Teknik Mesin Universitas Muhammadiyah Surakarta Volume 6 No.2 Juli 2005, halaman hal 55-62.

Rahdya Aramadhan Arendria, 2018. "Pengaruh Putaran Kipas Kondensor Terhadap Karakteristik Mesin Pendingin Jenazah Menggunakan Siklus Kompresi Uap” Teknik Mesin Fakultas Sains dan Teknologi Universitas Sanata Dharma. Yogyakarta.

David Armando Riswandi Putra, 2018. "Pengaruh Putaran Kipas Kondensor Terhadap Karakteristik Mesin AC Mobil” Teknik Mesin Fakultas Sains dan TeknologiUniversitas Sanata Dharma. Yogyakarta. 